\title{
Bean pod mottle virus Time of Infection Influences Soybean Yield, Yield Components, and Quality
}

\author{
E. Byamukama, Department of Plant Science, South Dakota State University, Brookings 57007; and A. E. Robertson and F. W. Nutter, Jr., \\ Department of Plant Pathology and Microbiology, Iowa State University, Ames 50011
}

\begin{abstract}
Byamukama, E., Robertson, A. E., and Nutter, F. W., Jr. 2015. Bean pod mottle virus time of infection influences soybean yield, yield components, and quality. Plant Dis. 99:1026-1032.

Bean pod mottle virus (BPMV) negatively affects soybean yield and quality, yet quantitative information on effect of time of BPMV infection on soybean yield and quality has not been reported. The impact of time of BPMV infection on soybean yield, yield components, and grain quality components were quantified during the 2006 and 2007 soybean growing seasons in Iowa. Soybean quadrats $(30 \mathrm{~cm}$ in length) were established within soybean plots ('NB3001') that consisted of six rows and were $7.5 \mathrm{~m}$ long. Quadrats were sampled 9 times during the 2006 growing season and 10 times during the 2007 growing season, beginning 25 days after planting in both years. Sap was extracted from leaflet samples from each quadrat and tested for the presence or absence of BPMV by enzyme-linked immunosorbent assay. The day of year (DOY) and quadrat position when BPMV was first detected within each plot were recorded and mapped. Soybean yield, number of pods per plant, number of seed per pod, and 100-seed weight for each quadrat were determined. The relationship between time (DOY) of BPMV infection and soybean yield, soybean yield components, and soybean grain quality were then

quantified using linear regression. DOY of BPMV infection within quadrats explained 89.7 and $57.9 \%$ of the variation in soybean grain yield in 2006 and 2007, respectively. Soybean yield damage functions (slopes) were 15.2 and $8.1 \mathrm{~kg} / \mathrm{ha}$ per day, respectively, indicating that, for each day that BPMV infection was delayed, soybean yield increased by $15.2 \mathrm{~kg} / \mathrm{ha}$ in 2006 and $8.1 \mathrm{~kg} / \mathrm{ha}$ in 2007 . The number of pods per plant increased by 0.15 pods for each day that BPMV infection was delayed $\left(R^{2}=72.8 \%\right)$ in 2006 but there was no relationship in 2007 . The 100 -seed weight had a significant linear relationship with the DOY when BPMV was first detected within quadrats in 2006 (slope $=0.013, R^{2}=86.3 \%$ ) but not in 2007. The percentage of mottled seed in 2006 decreased by $1 \%$ for each day that BPMV infection was delayed in $2006\left(R^{2}=\right.$ $87.4 \%$ ). Both protein and oil content were affected by the DOY that BPMV was first detected within quadrats in 2006 but not in 2007. This study demonstrated that time of BPMV infection can negatively affect soybean yield, yield components, and grain quality components when BPMV disease risk is high.
\end{abstract}

Bean pod mottle virus (BPMV) (genus Comovirus, family Comoviridae) is one of the most prevalent viruses infecting soybean worldwide (Byamukama et al. 2014, Giesler et al. 2002, Langham and Doxtader 2000), and is increasingly becoming a threat to soybean production in the United States (Giesler et al. 2002). Recent epidemics of BPMV in the United States have been attributed to increases in bean leaf beetles (Cerotorma trificurta Foster), the predominant vector of this virus (Byamukama et al. 2011, 2014; Giesler et al. 2002; Krell et al. 2003; Redinbaugh et al. 2010). Other sources of BPMV initial inoculum include seed-to-seedling transmission (generally $<0.1 \%$ ) (Krell et al. 2003) and alternative leguminous weed hosts (Krell et al. 2003). However, transmission by bean leaf beetles is by far the major mode of BPMV transmission (Byamukama et al. 2011; Krell et al. 2003).

BPMV negatively affects both soybean grain quantity and quality (Abney and Plopper 1994; Calvert and Ghabrial 1983; Cihlar and Langham 2004; Hill 2001; Hobbs et al. 2003; Kurtzweil et al. 2002; Ziems et al. 2001). Ross (1969) reported that BPMV infection resulted in yield reductions of up to $40 \%$. Mynre et al. (1973) found the effect of BPMV infection to be more detrimental to yield than yield reductions caused by soil water stress. Stukey et al. (1982) reported BPMV yield losses ranging from 23 to $44 \%$ in four cultivars inoculated at primary leaf growth stage. Hopkins and Mueller (1984) conducted a study that varied the time of soybean BPMV inoculation by mechanically inoculating two soybean cultivars with BPMV. They found the greatest yield loss (up to 52.6\%) to occur when soybean plants were inoculated at the earliest growth stage (V1). The same study reported a reduction

Corresponding author: F. W. Nutter, Jr.; E-mail: fwn@iastate.edu

Accepted for publication 2 February 2015.

http://dx.doi.org/10.1094/PDIS-11-14-1107-RE

(c) 2015 The American Phytopathological Society in the number of pods per plot in the earliest inoculated plots. Ross (1969) measured the response of three early- and late-planted soybean cultivars to infection by BPMV in plots that were either mechanically inoculated, screen caged, or left unprotected (to allow natural infection by viruliferous bean leaf beetles). In their study, BPMV infection caused yield losses of 2.3 to $19 \%$ in mechanically inoculated plots. Ziems et al. (2007) evaluated the response of more than 30 soybean cultivars that were mechanically inoculated with BPMV at the V3 and V4 growth stages. They reported yield losses of 0 to $75 \%$ and levels of percentage mottled seed ranging from 0 to $22 \%$.

In all previous reports, yield losses due to BPMV were estimated by mechanically inoculating all soybean plants within a treatment at one or more points in time. This scenario is highly unlikely to occur in natural BPMV epidemics in the field (Madden et al. 2000; Nutter 1997), because all plants within a plot (treatment) are not likely to become infected at one point in time. Mechanical inoculation of all plants at one point in time does not allow for yield compensation by neighboring healthy plants (Byamukama et al. 2011; Windham and Ross 1985). Therefore, yield losses reported in such studies may have overestimated the true impact of BPMV on yield and yield components. For example, barley yields were found to be more severely reduced in plots artificially inoculated with Barley yellow $d$ warf virus (BYDV) than naturally infected plots with the same level of BYDV incidence (Hoffman and Kolb 1998).

In addition to direct losses in yield, BPMV has been associated with increases in soybean seed coat mottling (Hobbs et al. 2003; Windham and Ross 1985; Ziems et al. 2001). Off-colored seed ( $>10 \%$ discoloration) is a primary factor that reduces the market grade of soybean (Sinclair 1995). However, soybean seed testing positive for BPMV do not always exhibit mottling. Hill (2001) tested two soybean seed lots for the presence of BPMV, one with discolored seed coats and the other without seed coat discoloration (normal). Both seed lots were found to have comparable BPMV levels. Although other environmental stresses have been reported to cause soybean seed coat mottling, the interaction between time of natural 
BPMV infection and soybean seed mottling has not been determined (Githiri et al. 2007; Koning et al. 2003; Morrison et al. 1998).

Quantitative information regarding the effect of time of BPMV infection on soybean yield, yield components, and seed quality under natural field epidemics remains largely unknown; however, such knowledge is important in justifying the need for the deployment of BPMV disease management tactics (Madden et al. 2000; Nutter 1997). Therefore, the objective of this study was to quantify the impact of time of BPMV infection on soybean yield, yield components, and grain quality.

\section{Materials and Methods}

Field plots. The soybean 'NE3001', which is susceptible to BPMV but is partially resistant to Soybean mosaic virus (SMV) (Hill et al. 2007), was planted on 5 May 2006 and 18 May 2007 at the Iowa State University Curtiss Research Farm located in Ames. Each soybean plot consisted of eight rows, $10.5 \mathrm{~m}$ in length, with a row spacing of $0.76 \mathrm{~m}$. The two outermost rows and $1.5 \mathrm{~m}$ of row on both ends of each plot served as borders to minimize edge effects. Soybean plots were located a minimum of $15 \mathrm{~m}$ from one another to minimize interplot interference. Thus, for purposes of data collection, plots were six rows by $7.5 \mathrm{~m}$ long. Each row was divided into $2530-\mathrm{cm}-$ long quadrats, resulting in 150 quadrats per plot. White wooden stakes ( $30 \mathrm{~cm}$ long) were used to delineate individual quadrats within each soybean plot. Soybean plants were then thinned to precisely four plants per quadrat on 24 May 2006 (19 days after planting) and 12 June 2007 (25 days after planting) to ensure uniform plant density in all quadrats and plots (Byamukama et al. 2011).

Treatments. Four treatments were used in an attempt to differentially affect the rate of quadrat-to-quadrat spread of BPMV, thereby obtaining a wide range of times when BPMV was first detected within quadrats (due to natural spread over time). Treatments consisted of (i) establishing a BPMV-inoculated point source (two quadrats per plot mechanically inoculated with BPMV), (ii) two applications of $\lambda$-cyhalothrin (Warrior 1EC; Syngenta Crop Protection, Greenville, NC), (iii) the establishment of a BPMVinoculated point source and two applications of $\lambda$-cyhalothrin, and (iv) a nontreated noninoculated control. The experimental design used was a complete randomized block design with four replicates. For the BPMV-inoculated point source treatments (treatments $i$ and iii), the four soybean plants located in the 13th quadrat positions of the center two rows (third and fourth rows) were mechanically inoculated with leaf sap extracted from BPMV-infected soybean plants that had previously been confirmed as being BPMV positive. The BPMV point sources were inoculated on 30 June 2006 and 13 July 2007 (26 days after planting in both years). Soybean plants in treatments ii and iii received two applications of the insecticide $\lambda$-cyhalothrin at the primary leaf growth stage (V1) and at the early reproductive growth stage (R2) (Krell et al. 2004). Insecticide was applied at a rate of $234 \mathrm{ml}$ a.i./ha using a $\mathrm{CO}_{2}$-powered sprayer (Bellspray Inc., Opelousas, LA) at 40 psi.

BPMV detection. To determine when individual soybean quadrats first tested positive for BPMV, all four soybean plants within each quadrat and all quadrats within a plot and for all treatments were sampled by removing a single leaflet from the youngest, fully expanded trifoliate leaf from each plant. The first sampling was conducted 25 days after planting and subsequent samplings were conducted every 8 to 11 days during the growing season until plant senescence. For inoculated plots, inoculation took place 1 day after the first sampling to assess for natural infection (if any). The four leaflets from each quadrat were placed together (bulk sample) in prelabeled (plot number, row number, quadrat number, and date of sampling) plastic sandwich-size bags. Quadrat samples were then stored at $4^{\circ} \mathrm{C}$ until sap extraction ( 2 to 4 days). Sap was extracted from the four leaflets sampled from each quadrat using a leaf press (Ravenel Specialties Corp., Seneca, SC). Plant sap was diluted by adding approximately $1.75 \mathrm{ml}$ of general extraction buffer ( $\mathrm{pH} 7.4)$, and extracted sap was stored in prelabeled 1.5-ml Eppendorf tubes at $-20^{\circ} \mathrm{C}$ until testing. BPMV was detected using enzyme-linked immunosorbent assay, as described previously (Byamukama et al. 2011). Quadrat sap samples were considered positive for BPMV if the absorbance value of a quadrat sample was greater than twice the value of the mean absorbance of the negative controls (four wells).

Yield data. The position and date when each soybean quadrat first tested positive for BPMV were recorded and mapped. Quadrats that tested negative for BPMV throughout the season were considered BPMV free. Prior to harvest, all soybean quadrats having the same date of sampling when BPMV was first detected from all the treatments were numbered from 1 to $n$, and 35 quadrats were randomly selected for harvest using a random number generator. Each randomly selected quadrat was hand harvested (on 12 October 2006 and 5 November 2007) and placed in prelabeled cotton bags identifying the plot number, row number, quadrat number, and date when BPMV was first detected. Because plants were manually harvested and processed, only three replicates were harvested (total of 12 plots). The impact of time of BPMV infection on yield and yield components (number of pods per plant, number of seed per pod, and 100-seed weight) was quantified. The number of pods per plant with respect to time of BPMV infection was determined and recorded. Pods within each quadrat sample were then shattered and the seed were cleaned by hand. The seed weight for each quadrat, number of seed per pod, and 100-seed weight were determined. Three grain quality components for each harvested soybean quadrat were quantified: the percentage of mottled seed, protein content $(\%)$, and oil content $(\%)$. Seed coat mottling was defined as any seed that had seed coat discoloration.

Grain yield (as affected by time of BPMV infection) was determined by averaging the grain weight of soybean quadrats for each BPMV infection time. Estimated yield for each plot was obtained as follows:

$$
Y_{p}=\sum_{t=1}^{n} \eta_{t} \bar{y}_{t}
$$

Table 1. Analysis of variance for the estimated yield as affected by different treatments in 2006 and 2007 soybean growing seasons ${ }^{\mathrm{z}}$

\begin{tabular}{lccc}
\hline Source & DF & MS & $\boldsymbol{P}>\boldsymbol{F}$ \\
\hline 2006 & & & \\
Rep & 2 & 14,680 & 0.2294 \\
Treatment & 3 & 6,417 & 0.5237 \\
Error & 6 & 7,724 & $\ldots$ \\
2007 & & & \\
Rep & 2 & 373.88 & 0.4813 \\
Treatment & 3 & 4,169 & 0.0115 \\
Error & 6 & 2,708 & $\ldots$ \\
\hline
\end{tabular}

$\mathrm{z}$ Treatments were Bean pod mottle virus (BPMV) point source inoculation, two $\lambda$-cyhalothrin sprays, BPMV point source inoculation and two $\lambda$-cyhalothrin sprays, and nontreated and noninoculated (control). Soybean (NE3001) was planted at the Iowa State University Research Curtiss Farm near Ames in both years. $\mathrm{DF}=$ degrees of freedom and $\mathrm{MS}=$ mean square.

Table 2. Treatment means of estimated soybean yield in 2006 and 2007 soybean growing seasons

\begin{tabular}{lcc}
\hline & \multicolumn{2}{c}{ Estimated yield (kg/ha) } \\
\cline { 2 - 3 } Treatment $^{\mathbf{z}}$ & $\mathbf{2 0 0 6}$ & $\mathbf{2 0 0 7}$ \\
\hline BPMV PS, nonsprayed & $4,191.68 \mathrm{a}$ & $3,127.30 \mathrm{~b}$ \\
Two foliar sprays & $4,156.06 \mathrm{a}$ & $3,182.62 \mathrm{a}$ \\
PS + two foliar sprays & $4,122.55 \mathrm{a}$ & $3,195.87 \mathrm{a}$ \\
Noninoculated nonsprayed control & $4,230.04 \mathrm{a}$ & $3,123.53 \mathrm{~b}$ \\
\hline
\end{tabular}

${ }^{y}$ Estimated yield for each plot was obtained by averaging the grain weight of soybean quadrats harvested for each Bean pod mottle virus (BPMV) infection time multiplied by total number of quadrats with the same detection date and adding up yield estimates for all dates in a plot. Means in a column with the same letter are not significantly different from each other at $P=$ 0.05 .

${ }^{\mathrm{z}}$ BPMV point source (PS) was obtained by inoculating the 13th quadrat in the center two rows. Two $\lambda$-cyhalothrin foliar sprays: first spray was at the V1 and second spray was at $\mathrm{R} 2$ growth stage. 
where $Y_{p}$ is the plot yield, $\eta_{t=1}$ is the number of quadrats that tested positive for BPMV at the first time of sampling, $\bar{y}_{t=1}$ is the average yield for all BPMV-positive quadrats on the first sampling date across the replicates, $\eta_{t=n}$ is the number of quadrats that first tested positive for BPMV at the $n$th time of sampling, and $\bar{y}_{t=n}$ is the average yield for all BPMV-positive quadrats on the $n$th sampling date until all 150 quadrats were assigned a time of infection-yield value. The percentage of mottled seed for each quadrat was determined by expressing mottled seed as the percentage of the total number of seed within each quadrat. Seed from each harvested quadrat were tested
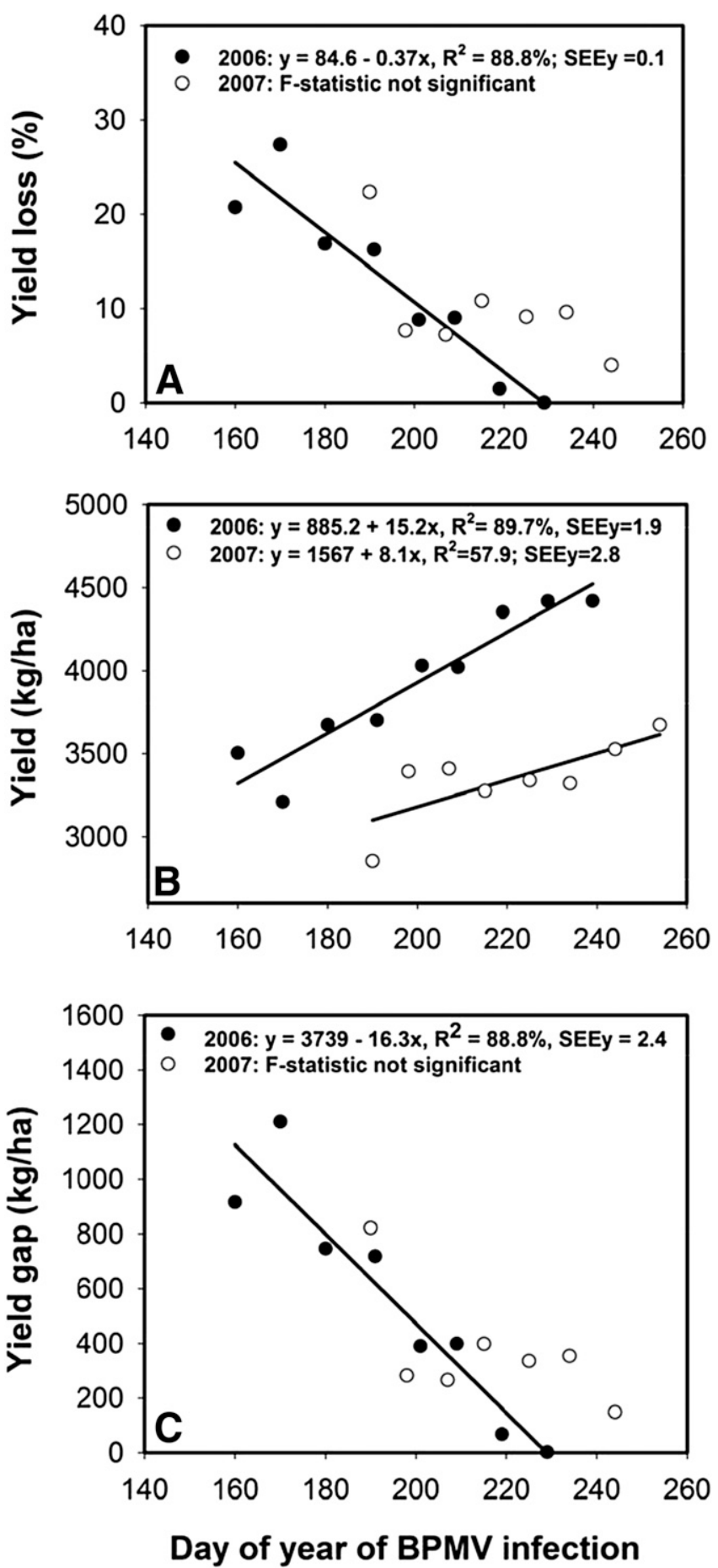

Fig. 1. Relationship between day of year of Bean pod mottle virus infection and $\mathbf{A}$, percent soybean yield loss in 2006 (solid circle) and 2007 (open circle); B, yield in 2006 (solid circle) and 2007 (open circle); and C, yield gap in 2006 (solid circle) and 2007 (open circle). Soybean (NE3001) was planted at the lowa State University Research Curtiss Farm near Ames in both years. for protein (\%) and oil content (\%) using near-infrared spectroscopy (Infratec-1225, Eden Prairie, MN; Singer et al. 2008).

Data analysis. Progress of BPMV in soybean plots for the different treatments, rate of change in percentage of new soybean quadrats testing positive for BPMV in each treatment, and area under BPMV incidence progress curves (AUIC) have previously been published (Byamukama et al. 2011). To determine the effect of treatment on yield and yield components, yield, number of pods per plant, number of seed per pod, and 100-seed weight were subjected to analysis of variance using GLM procedure in SAS (SAS Institute Inc., Cary, NC). Because treatments did not significantly affect soybean grain weight, number of pods per plant, and 100-seed weight in 2006, data from soybean quadrats with the same infection date were pooled across treatments. In 2007, there was heavy aphid infestation (>250 aphids/plant threshold in noninsecticide-treated plots); therefore, to avoid confound effects of aphid infestation on yield, only foliar insecticide-treated plots were considered for yield and yield components analysis.

Yield, yield components, and grain quality components for each infection date were graphed against the day of year (DOY) when BPMV was first detected in a quadrat. DOY was used instead of growth stages to provide a quantitative variable for regression analysis. Because each of these curves was linear (Cornell and Berger 1987; Nutter 1997), these data were subjected to linear regression analysis (Gomez and Gomez 1984). Percent yield loss was obtained by expressing the difference between yield for each respective time of BPMV infection and yield from non-BPMV detection (healthy) quadrats expressed as a percentage relative to the yield of nonBPMV-detected quadrats. Yield gap data (difference between yield of each infection date and yield from non-BPMV-detected quadrats) were also subjected to linear regression analysis. Percent mottled seed data were linearized by natural $\log$ transformation before the regression analysis.

\section{Results}

Treatments in 2006 did not have a significant effect on estimated yield; however, treatments that received foliar insecticide in 2007 had significantly higher estimated yield (Tables 1 and 2). Time of BPMV infection (DOY) had a significant negative linear relationship with percent soybean yield loss in 2006 but not in 2007 (Fig. 1A). The time of BPMV infection explained $88.8 \%$ of the variation in percent soybean yield loss in 2006 . When grain yield was used as

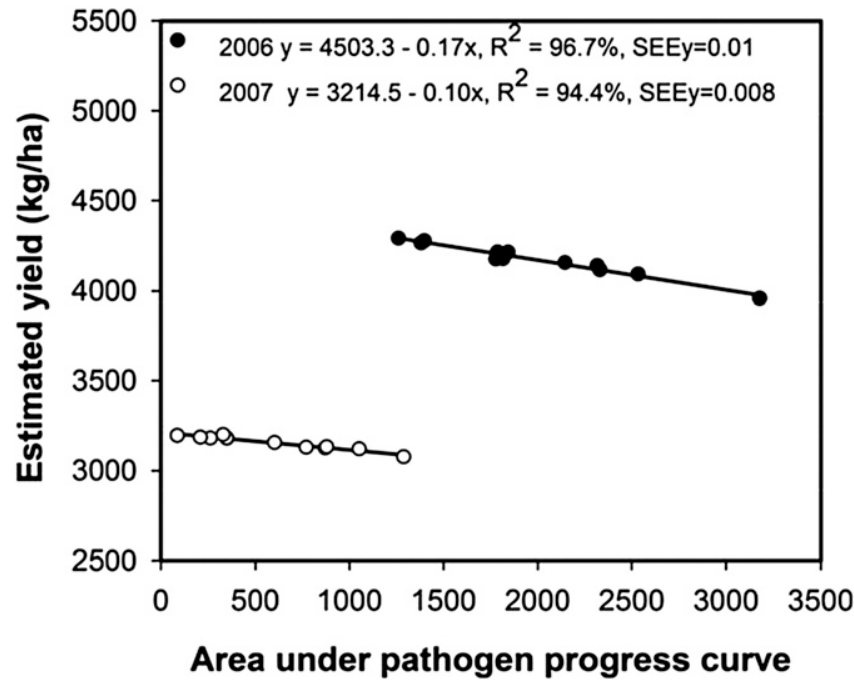

Fig. 2. Relationship between estimated yield and the area under the pathogen progress curve in 2006 and 2007. Estimated yield was obtained by accumulating average yield from quadrats that had the same Bean pod mottle virus (BPMV) infection date for all the infection dates and for non-BPMVV infection (healthy) quadrats for each treatment. The area under the pathogen progress curve was obtained by calculating the area under the BPMV incidence graph for each treatment 
the dependent variable, grain yield had a positive linear relationship with time of BPMV infection in both 2006 and 2007 (Fig. 1B). The damage function (slope) relating time of BPMV infection to grain yield was $15.2 \mathrm{~kg} / \mathrm{ha}$ per day in 2006 and $8.1 \mathrm{~kg} / \mathrm{ha}$ per day in 2007, indicating that, for 1 day that BPMV infection was delayed, soybean yield increased by 15.2 and $8.1 \mathrm{~kg} / \mathrm{ha}$ per day in 2006 and 2007, respectively. When the yield gap was used as the dependent variable, yield gap had a significant negative linear relationship with date of BPMV infection, explaining $88.8 \%$ of the variation in yield gap (Fig. 1C) for 2006. However, as with the percent yield loss model, there was no significant relationship between time of BPMV infection $(x)$ and yield gap $(y)$ for 2007.
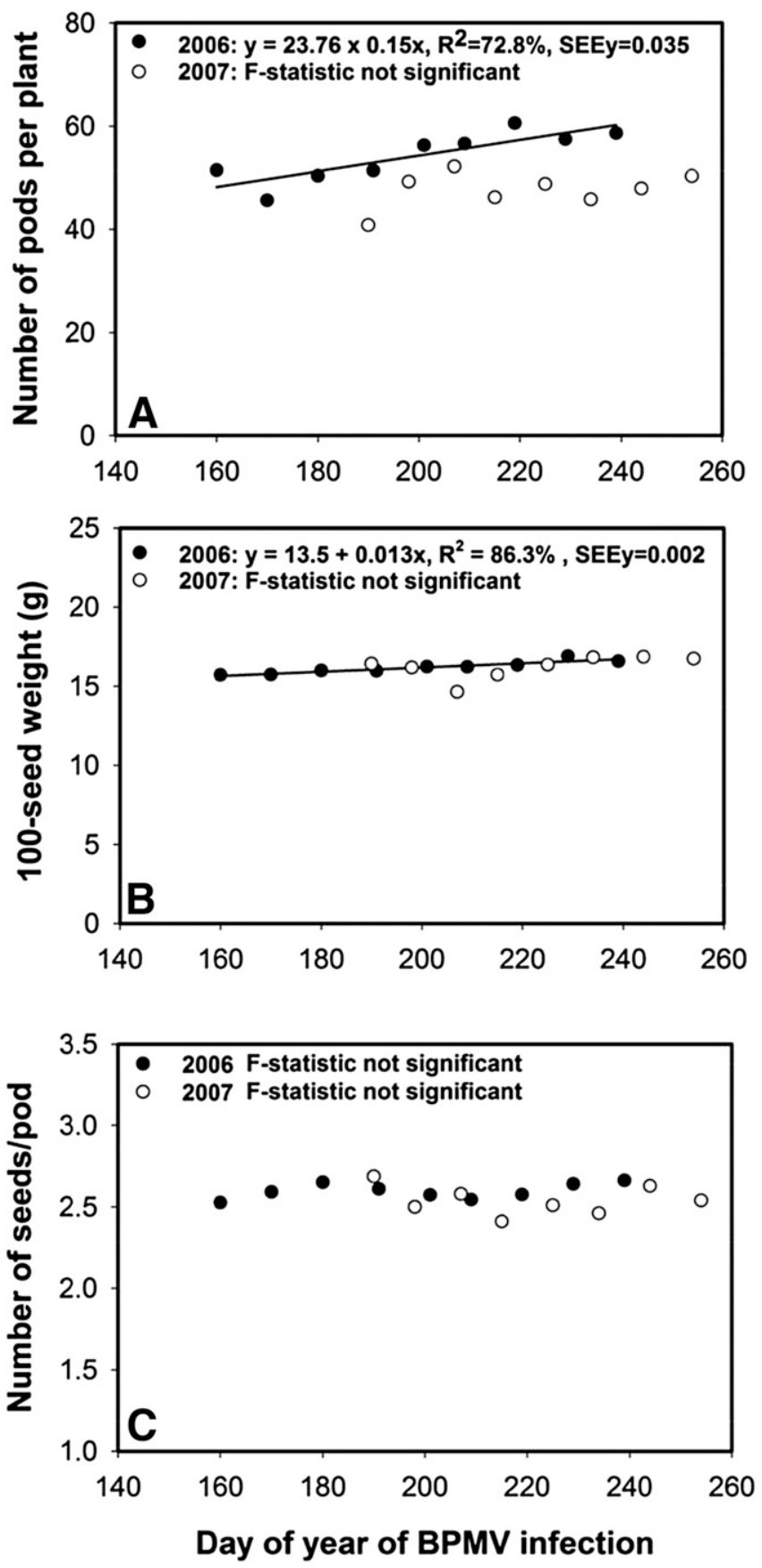

Fig. 3. Relationship between $\mathbf{A}$, number of pods per plant and day of year when Bean pod mottle virus (BPMV) was first detected within soybean quadrats in 2006 (solid circle) and 2007 (open circle); B, 100-seed weight and day of year when BPMV was first detected in soybean quadrats in 2006 (solid circle) and 2007 (open circle); and $\mathbf{C}$, number of seeds per pod and day of year when BPMV was first detected in soybean quadrats in 2006 (solid circle) and 2007 (open circle).
The AUIC had a strong linear relationship with estimated soybean yield per plot in both years $(P<0.0001$; Fig. 2$)$. Coefficient of determination $\left(R^{2}\right)$ was 96.7 and $94.4 \%$ in 2006 and 2007, respectively, indicating that the AUIC best described the variation in yield in both years (Fig. 2).

Time of BPMV infection in soybean quadrats significantly affected the number of pods per plant in 2006, with a slope of 0.15 $\left(R^{2}=72.8 \%\right)$, indicating that there was a gain of 0.15 pods per plant per day for each day of delay in BPMV infection (Fig. 3A). In 2007, there was no linear relationship between number of pods per plant and DOY that BPMV was first detected.

The DOY when BPMV was first detected within a quadrat significantly affected the 100 -seed weight, with a slope of $0.013 \mathrm{~g} / \mathrm{day}$
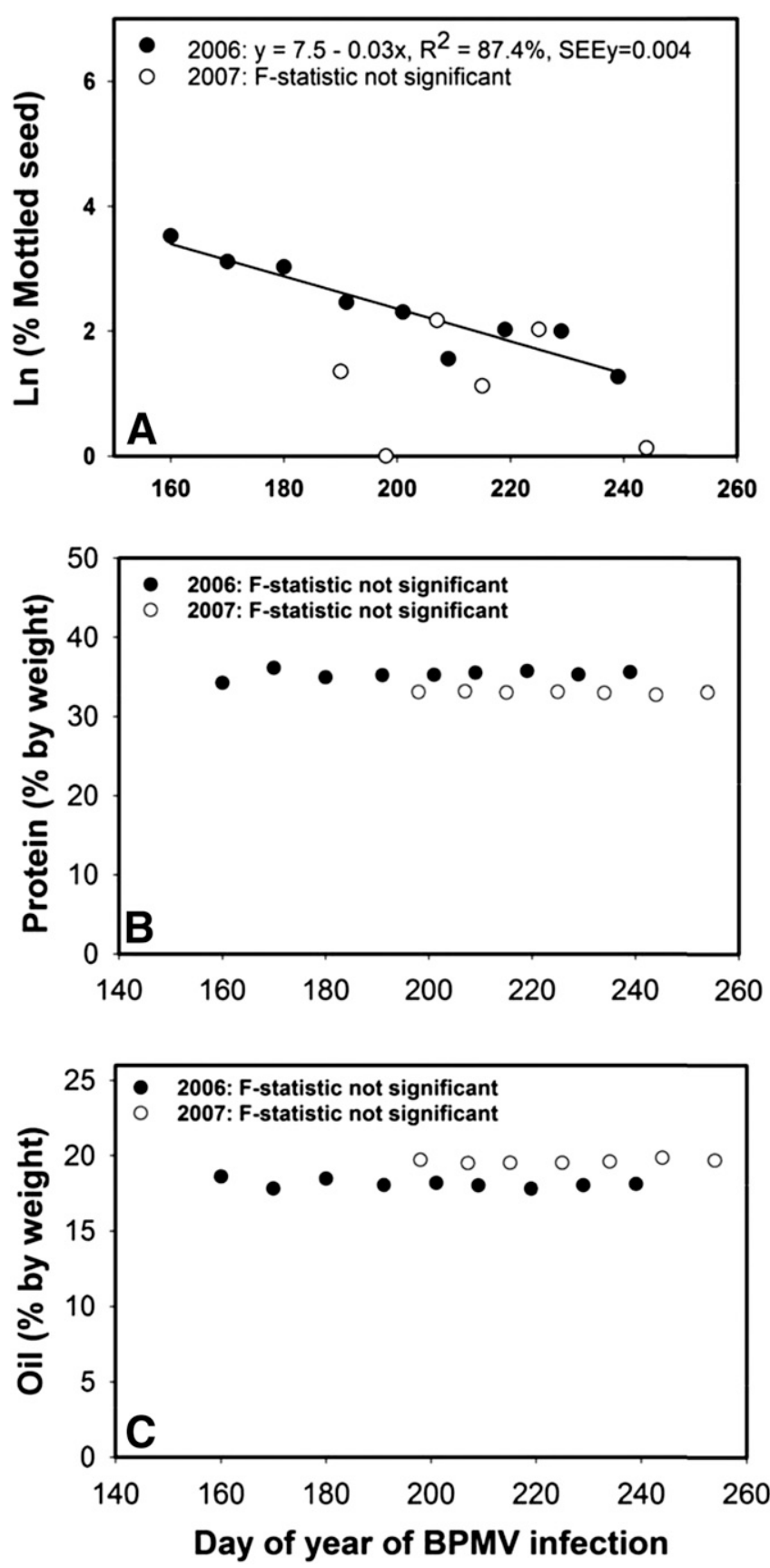

Fig. 4. Relationship between A, In percent mottled seed and day of year of Bean pod mottle virus (BPMV) infection in a soybean quadrat in 2006 (solid circle) and 2007 (open circle); B, percent protein content and day of year of BPMV infection in a soybean quadrat in 2006 (solid circle) and 2007 (open circle); and C, percent oil content and day of year of BPMV infection in a soybean quadrat in 2006 (solid circle) and 2007 (open circle). 
$\left(R^{2}=86.3 \%\right)$ in 2006. This indicates that, for every day that BPMV infection was delayed, there was a gain of $0.013 \mathrm{~g}$ in 100 -seed weight (Fig. 3B). The 100-seed weight in 2007 was not linearly related with time of BPMV infection in a quadrat. Number of seed per pod was not affected by date of BPMV infection within quadrats in either 2006 or 2007 (Fig. 3C).

The DOY that BPMV was first detected within a quadrat significantly affected the percentage of mottled seed in 2006 but not in 2007 (Fig. 4A). DOY of BPMV first infection explained $82.8 \%$ of the variation in natural percent seed mottling (log transformed) in 2006. The slope value was $-1 \%$ (back transformed) in 2006, indicating that percent mottled seed decreased by $1 \%$ for each day that BPMV infection was delayed.

Protein and oil content had no significant linear relationship with the DOY when BPMV was detected in a quadrat in both years (Fig. $4 \mathrm{C}$ and D).

\section{Discussion}

This study provides new quantitative information concerning the impacts of BPMV time of infection on percent yield loss, yield and yield gaps, yield components, and grain quality. Quantitative knowledge concerning the impacts of pathogen populations on yield loss is of critical importance if producers are to make cost-effective disease management decisions (Madden et al. 2007; Nutter 2007). Quantitative yield loss data are also required to facilitate efficient allocation of management resources and as a basis to conduct science-based evaluations of potential disease management practices (Cooke 2006; McKirdy et al. 2002; Redinbaugh et al. 2010; Nutter 2007).

This study monitored soybean quadrats for natural BPMV infection at different growth stages and related time of BPMV infection to critical yield response variables. In both years, time of BPMV infection significantly affected soybean yield, because soybean yield increased in both growing seasons as the DOY that BPMV was first detected was delayed. Conversely, yield loss (\%) and yield gaps (\%) decreased with respect to delays in time of BPMV infection.

The imposed treatments had varying significance on soybean yield in the 2 years. Lack of significant treatment effect on yield in 2006 may be attributed to high BPMV pressure resulting in the wide spread of BPMV among the quadrats in all treatments (Byamukama et al. 2011). In contrast, BPVM pressure in 2007 was relatively low, and higher yield in plots that received insecticide sprays was mainly due to the control of aphids. Foliar insecticide application for virus management has not been successful in many instances because insect vectors can move and transmit viruses before being killed by the insecticide (Perring et al. 1999). In the case of BPMV management, insecticide seed treatments may be more effective than foliar-applied insecticide to minimize BPMV spread.

Quantifying the impact of plant pathogens on crop yield is an exercise in stimulus-response, whereby the stimulus $(x)$ is a measure of the stress exerted by a disease or pathogen population on a population of plants, and $y$ is a measure of the plant population response to that stress. The two most common measures of disease (or pathogen) stress (stimuli) are incidence or severity (Madden et al. 2007; Nutter 1997, 2007; Nutter and Guan 2001). In 1986, Nutter et al. (1989) proposed a third measure of pathogen or disease stress related to time of infection (detection) that could be used to quantify yield loss in the Tobacco etch virus-pepper pathosystem in Georgia. Madden et al. (2000) later proposed that the use of time-of-infection models to predict yield loss would be an appropriate method in plant pathosystems involving systemic infections (e.g., plant viruses, phytoplasmas, and soilborne pathogens). In this study, time of BPMV infection (stimulus) was used to predict the plant response (yield).

The greatest yield loss (27\%) occurred in quadrats that had BPMV first detected on or before DOY 180 (growth stage V4 to V5) in 2006. Although the largest change in BPMV incidence during either of two soybean growing seasons occurred after DOY 191 for 2006 and DOY 207 for 2007 (R2 growth stage = full flower setting), the yield losses associated with BPMV infection after the R2 growth stage was negligible. Previous studies that have employed artificial (mechanical) inoculation methods have also reported that negligible yield losses due to BPMV occurred when soybean plants were mechanically inoculated after the R2 growth stage (Hopkins and Mueller 1984; Ziems et al. 2007).

Percent yield loss data are the statistic most often cited by researchers to justify the need for research dollars from granting agencies and policy makers. Advantages are that this statistic provides a quantitative measure of yield loss that is easily comprehended by the general public and administrators. The main disadvantage, however, is that a dollar figure cannot be attached to percentage data unless the actual and potential yields are known (Nutter and Guan 2001; Nutter 2007). The calculation and use of yield gap data can overcome the disadvantages of percentage yield loss data because yield gap data (attainable yield minus actual yield) represent actual units of yield (e.g., kilograms per hectare, bushels per acre, and so on) (McKirdy et al. 2002). One advantage in calculating yield gaps is that yield gaps caused by various biotic and abiotic stresses can be ranked in terms of actual units of yield lost. Once ranked, these data can then be used to prioritize research projects aimed at narrowing these yield gaps
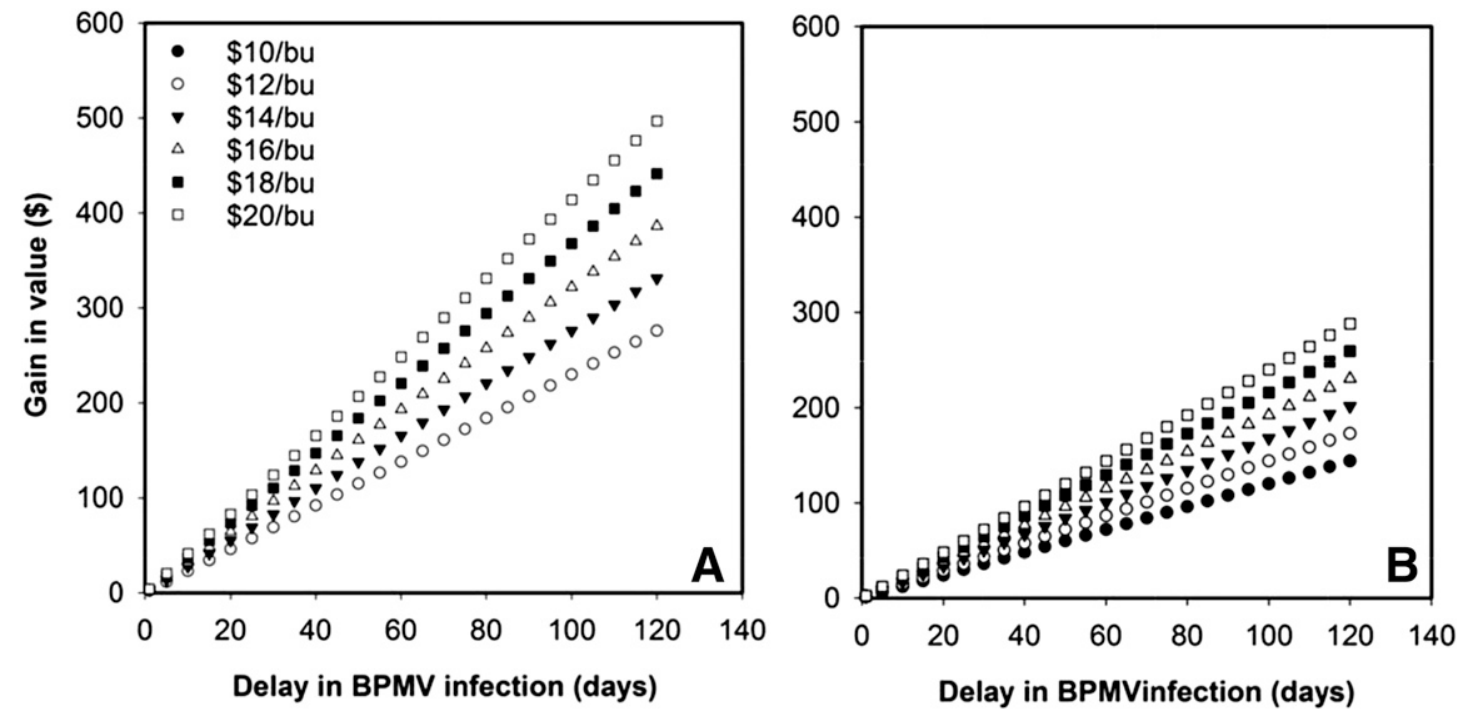

Fig. 5. Theoretical gain in revenue accrued with delayed Bean pod mottle virus (BPMV) infection (infection) for different soybean price scenarios for A, 2006 and B, 2007. Gain in revenue was obtained by multiplying the price per bushel and the damage functions (slopes) relating soybean yield (bushels per day) versus the day of year that BPMV was first detected within soybean quadrats. 
(i.e., producers to come closer to reaching attainable yields). The International Rice Research Institute has used this approach to successfully compete for research dollars provided by the World Bank and other funding agencies (Chiarappa 1981).

The two most prevalent soybean viruses in Iowa are BPMV and SMV. Of these two viruses, it is likely that, per unit virus incidence, BPMV causes greater yield losses than SMV. This is because the spatial pattern of BPMV-infected quadrats (and plants) in the field has been shown to be highly clustered (Byamukama et al. 2011, Redinbaugh et al. 2010), whereas the spatial pattern of SMV has been shown to be mostly random over time (Steinlage et al. 2002). A clustered spatial pattern of infected plants limits yield compensation from neighboring plants (and quadrats). This is because infected plants are neighbored by plants also most likely to be infected, thereby limiting yield compensation from healthy plants (Madden et al. 2007). However, in pathosystems with random spatial patterns, plants neighboring infected plants are likely to be healthy (not infected), and their growth and development has the potential to compensate for infected plants.

The AUIC explained up to $96.4 \%$ of the variation in soybean yield. Madden et al. (2000) reported area under the curve to be a better predictor of yield loss because this variable provides a quantitative measure of the entire epidemic rather than assessments performed at a single point in time. Soybean plots that had the highest AUIC values also had lowest yields.

The monetary impact of BPVM on soybean can be determined by coupling price scenarios with damage functions (slopes) relating time of BPMV infection to yield (kilograms per hectare). For example, Nutter and Guan (2001) coupled the highest, lowest, and quartile prices for square bales of hay with damage functions relating percentage defoliation caused by foliar pathogens of alfalfa to alfalfa yield. By coupling damage functions for the relationship between time of BPMV infection and soybean price scenarios ranging from $\$ 10$ to 20 per bushel (yield gap [bushels per day] $\times$ price per bushel), we found that, for each day that BPMV infection was delayed, gross farm revenue (dollars per hectare) would have increased by $\$ 28.16$ and 14.80 in 2006 and 2007, respectively (Fig. 5).This new information is important to soybean producers, who are continually challenged with making disease management decisions that will directly affect farm revenue (Bradshaw et al. 2008; Byamukama et al. 2011, 2014; Cooke 2006, Nutter 2007). This gain in farm revenue would be of tremendous benefit to producers, especially during a time of high risk for BPMV spread (i.e., years with high bean leaf beetle populations) (Byamukama et al. 2011, 2014, Nutter 1997). Management tactics that could potentially delay BPMV infection in high-risk years include use of insecticide seed treatments (Bradshaw et al. 2008), foliar insecticides (Bradshaw et al. 2008), resistant or tolerant varieties (Hill et al. 2007), or delayed planting (Krell et al. 2003). Seed companies could also select low-risk planting sites (based on lower winter temperatures and other site risk factors) that reduce initial inoculum risk arising from BPMV-infected seed sources (Byamukama et al. 2014; Krell et al. 2003, Nutter 2007). This study also provides new science-based information concerning the impact of BPMV time of infection on soybean yield components. Of the four soybean yield components (number of plants per unit area, number of pods per plant, number of seed per pod, and 100-seed weight), only two yield components were affected by time of BPMV infection. Infection by BPMV does not cause plant death and, therefore, the number of plants per unit area is not affected by time of BPMV infection. The number of soybean pods per plant, however, was significantly affected by time of BPMV infection in 2006. The earlier that BPMV was detected within soybean quadrats, the lower was the number of pods per plant. Reductions in the number of pods per plant was likely due to flower abortion caused by BPMV infection. Flower abortion caused by plant virus infection has been reported to occur in several other virus pathosystems (Nutter et al. 1989; Zimmer et al. 1992). Our study demonstrated that there was no effect of BPMV time of infection on the number of seed per pod, as shown by the lack of a significant relationship relating the number of seed per pod to time of BPMV infection. This suggests that NE3001 soybean is tolerant to BPMV for this yield component.
Lack of a significant linear relationship for yield components in 2007 may be attributed to confounding effects of the weather. The 2007 soybean-growing season in Ames, IA was characterized by low moisture and cooler temperatures that may have minimized the negative impact of BPMV infection on soybean yield components. These conditions also did not favor the wide spread of BPMV compared with the 2006 soybean-growing season, because rows closed about 2 weeks later in 2007, thereby limiting across-row virus spread by BPMV-infested bean leaf beetles.

Soybean grain quality was also negatively affected by time of BPMV infection. Our results show that time of BPMV infection significantly increased the percentage of mottled seed in harvested grain. Previous reports concerning the impact of BPMV on mottled seed have been largely based upon studies that had soybean plants mechanically inoculated at a single point in time (Hobbs et al. 2003; Ziems et al. 2001). In our study, the slope relating time of BPMV infection to percentage of mottled seed was high in 2006, indicating that there was a significant decline in percent mottled seed as BPMV infection was delayed. Although other biotic and abiotic factors have been found to be associated with soybean seed mottling, our study confirms that early-season infection by BPMV increases the percentage of mottled seed. In the Tomato spotted wilt tospovirus-tomato pathosystem, however, seed quality can be adversely affected regardless of time of virus infection (Moriones et al. 1998). Although other stresses have been reported to increase protein content in soybean (Morrison et al. 1998; Rose 1988), we found that time of BPMV infection did not significantly affect protein and oil content in the soybean variety employed in our study.

Quantification of yield losses is important for assessing the economic importance of plant pathogens and justifying the need for management. Moreover, quantitative information on yield loss can be used to quantify and compare the return on investment that various integrated management tactics may have on plant pathosystems (Nutter and Guan 2001; Savary et al. 2006). In our study, BPMV yield loss was as high as $27 \%$ which, when coupled with price reductions due to seed quality (mottling), may lead to additional reductions in farm revenue.

\section{Acknowledgments}

We thank C. Hurburgh's lab for the assistance with soybean protein and oil analysis and M. Minsini for the help processing seed samples. This research was funded by check-off funds from the Iowa Soybean Association.

\section{Literature Cited}

Abney, T. S., and Plopper, L. D. 1994. Effects of Bean pod mottle virus on soybean seed maturation and seedborne Phomopsis spp. Plant Dis. 78:33-37.

Bradshaw, D. J., Rice, M., and Hill, J. H. 2008. Evaluation of management strategies for bean leaf beetles (Coleoptera: Chrysomelidae) and Bean pod mottle virus (Comoviridae) in soybean. J. Econ. Entomol. 101:1211-1227.

Byamukama, E., Robertson, A. E., and Nutter, F. W., Jr. 2011. Quantifying the within-field temporal and spatial dynamics of Bean pod mottle virus in soybean. Plant Dis. 95:126-136.

Byamukama, E., Robertson, A., and Nutter, F. W., Jr. 2014. Geospatial analyses of Bean pod mottle virus of soybean at different spatial scales. Phytopathology 104:365-378.

Calvert, L. A., and Ghabrial, S. A. 1983. Enhancement by Soybean mosaic virus of Bean pod mottle virus titer in doubly infected soybean. Phytopathology 73: 992-997.

Chiarappa, L. 1981. Crop Loss Assessment Methods-Supplement 3. Food and Agriculture Organization of the United Nations, Commonwealth Agricultural Bureaux, Alben Press, Oxford, UK

Cihlar, C. L., and Langham, M. A. C. 2004. BPMV effects on yield and test weight of ten soybean lines. (Abstr.) Phytopathology 94:S157.

Cooke, B. M. 2006. Disease assessment and yield loss. Pages 43-80 in: The Epidemiology of Plant Diseases, 2nd ed. B. M. Cooke, G. D. Jones, and B. Kaye, eds. Springer, The Netherlands.

Cornell, J. A., and Berger, R. D. 1987. Factors that influence the value of the coefficient of determination in simple linear and nonlinear regression models. Phytopathology 77:63-70

Giesler, L. J., Ghabrial, S. A., Hunt, T. E., and Hill, J. H. 2002. Bean pod mottle virus: A threat to U.S. soybean production. Plant Dis. 86:1280-1289.

Githiri, S. M., Yang, D., Khan, N. A., Xu, D., Komatsuda, T., and Takahashi, R 2007. QTL analysis of low temperature-induced browning in soybean seed coats. J. Hered. 98:360-366

Gomez, K. A., and Gomez, A. A. 1984. Statistical Procedures for Agricultural Research, 2nd ed. John Wiley \& Sons, New York. 
Hill, J. H. 2001. Virus-induced soybean seed problems. In: Integrated Crop Management Newsletter Issue No. IC-79-180. Iowa State University, Ames.

Hill, J. H., Koval, N. C., Gaska, J. M., and Grau, C. R. 2007. Identification of field tolerance to Bean pod mottle and Soybean mosaic viruses in soybean. Crop Sci. 47:212.

Hobbs, H. A., Hartman, G. L., Wang, Y., Hill, C. B., Bernard, R. L., Pedersen, W. L., and Domier, L. L. 2003. Occurrence of seed coat mottling in soybean plants inoculated with Bean pod mottle virus and Soybean mosaic virus. Plant Dis. 87:1333-1336.

Hoffman, T. K., and Kolb, F. L. 1998. Effects of Barley yellow dwarf virus on yield and yield components of drilled winter wheat. Plant Dis. 82:620-624.

Hopkins, J. M., and Mueller, A. J. 1984. Effect of Bean pod mottle virus on soybean yield. J. Econ. Entomol. 77:943-947.

Koning, G., TeKrony, D. M., and Ghabrial, S. A. 2003. Soybean seedcoat mottling: Association with Soybean mosaic virus and Phomopsis spp. seed infection. Plant Dis. 87:413-417.

Krell, R. K., Pedigo, L. P., Hill, J. H., and Rice, M. E. 2004. Bean leaf beetle (Coleoptera: Chrysomelidae) management for reduction of Bean pod mottle virus. J. Econ. Entomol. 97:192-202.

Krell, R. K., Pedigo, L. P., Hill, J. H., and Rice, M. E. 2003. Potential primary inoculum sources of Bean pod mottle virus in Iowa. Plant Dis. 87:1416-1422.

Kurtzweil, N. C., Grau, C. R., and Gaska, J. M. 2002. Impact of soybean viruses on yield and seed quality. Pages 90-93 in: Proc. WI Fertilizer, Aglime and Pest Manage. Conf. Madison, WI.

Langham, M. A. C., and Doxtader, D. C. 2000. Incidence of Bean pod mottle comovirus infecting soybean in South Dakota. (Abstr.) Phytopathology 90:S45.

Madden, L. V., Hughes, G., and Irwin, M. E. 2000. Coupling disease progresscurve and time-of-infection functions for predicting yield loss of crops. Phytopathology 90:788-800.

Madden, L. V., Hughes, G., and van den Bosch, F. 2007. The Study of Plant Disease Epidemics. American Phytopathological Society, St. Paul, MN.

McKirdy, S. J., Jones, R. A. C., and Nutter, F. W., Jr. 2002. Quantification of yield losses caused by Barley yellow dwarf in oats and wheat in Western Australia. Plant Dis. 86:769-773.

Moriones, E., Aramburu, J., Riudavets, J., Arnó, J., and Laviña, A. 1998. Effect of plant age at time of infection by Tomato spotted wilt tospovirus on the yield of field-grown tomato. Eur. J. Plant Pathol. 104:295-300.

Morrison, M. J., Pietrzak, L. N., and Voldeng, H. D. 1998. Soybean seed coat discoloration in cool-season climates. Agron. J. 90:471-474.

Mynre, D. L., Pitre, H. N., Haridasan, M., and Hesketh, J. D. 1973. Effect of Bean pod mottle virus on yield components and morphology of soybeans in relation to soil water regimes: A preliminary study. Plant Dis. Rep. 57:1050-1054.

Nutter, F. W., Jr. 1997. Quantifying the temporal dynamics of plant virus epidemics: A review. Crop Prot. 16:603-618.
Nutter, F. W., Jr. 2007. The role of plant disease epidemiology in developing successful integrated disease management programs. Pages 43-77 in: General Concepts in Integrated Pest and Disease Management. A. Ciancio and K. G. Mukerji, eds. Springer-Verlag, Dordrecht, The Netherlands.

Nutter, F. W., Jr., and Guan, J. 2001. Disease losses. Pages 340-351 in: Encyclopedia of Plant Pathology. O. C. Maloy and T. D. Murray, eds. John Wiley and Sons, Inc., New York.

Nutter, F. W., Jr., Kuhn, C. W., and All, J. N. 1989. Models to estimate yield losses in bell pepper caused by tobacco etch virus epidemics. (Abstr.) Phytopathology 79:1213.

Perring, T. M., Gruenhagen, N. M., and Farrar, C. A. 1999. Management of plant viral diseases through chemical control of insect vectors. Annu. Rev. Phytopathol. 44:457-481.

Redinbaugh, M. G., Molineros, J. E., Vacha, J., Berry, S. A., Hammond, R. B., Madden, L. V., and Dorrance, A. E. 2010. Bean pod mottle virus spread in insect-feeding-resistant soybean. Plant Dis. 94:265-270.

Rose, I. A. 1988. Effects of moisture stress on the oil and protein components of soybean seeds. Aust. J. Agric. Res. 39:163-170.

Ross, J. P. 1969. Effect of time and sequence of inoculation of soybeans with soybean mosaic and Bean pod mottle viruses on yields and seed characters. Phytopathology 59:1404-1408.

Savary, S., Teng, P. S., Willocquet, L., and Nutter, F. W., Jr. 2006. Quantification and modeling of crop losses: A Review of purposes. Annu. Rev. Phytopathol. 44:89-112.

Sinclair, J. 1995. Reevaluation of grading standards and discounts for fungusdamaged soybean seeds. J. Am. Oil Chem. Soc. 72:1415-1419.

Singer, W. J., Logsdon, D. S., and Meek, D. W. 2008. Soybean growth and seed yield response to tillage and compost. Agron. 100:1039-1046.

Steinlage, T. A., Hill, J. H., and Nutter, F. W., Jr. 2002. Temporal and spatial spread of soybean mosaic virus (SMV) in soybeans transformed with the coat protein gene of SMV. Phytopathology 92:478-486.

Stuckey, R. E., Ghabrial, S. A., and Reicosky, D. A. 1982. Increased incidence of Phomopsis spp. in seeds from soybean infected with Bean pod mottle virus. Plant Dis. 66:826-829.

Windham, M. T., and Ross, J. P. 1985. Transmission of Bean pod mottle virus in soybeans and effects of irregular distribution of infected plants on plant yield. Phytopathology 75:310-313.

Ziems, A., Giesler, L. J., and Graef, G. L. 2001. Effect of Bean pod mottle virus on soybean seed quality. (Abstr.) Phytopathology 91:S100.

Ziems, A. D., Giesler, L. J., and Graef, G. L. 2007. Response of soybean cultivars to Bean pod mottle virus infection. Plant Dis. 91:719-726.

Zimmer, R. C., Myers, K., Haber, S., Campbell, C. G., and Gubbels, G. H. 1992. Tomato spotted wilt virus, a problem on grass pea and field pea in the greenhouse in 1990 and 1991. Can. Plant Dis. Surv. 72:29-31. 